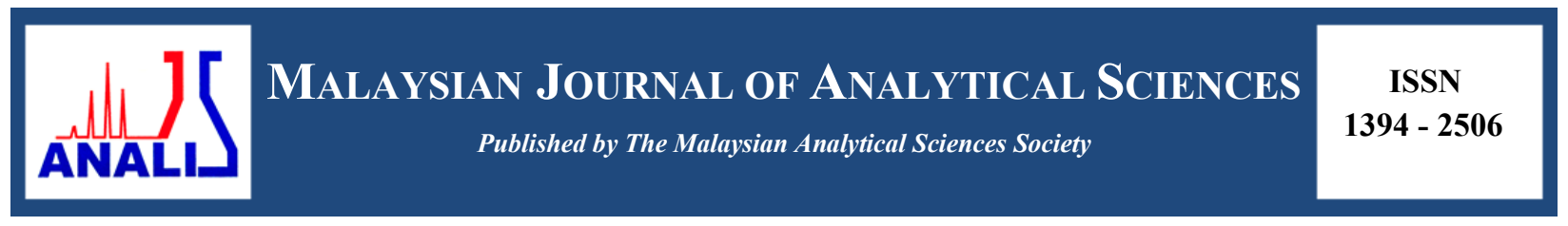

\title{
SYNTHESIS AND X-RAY SINGLE CRYSTAL STUDY OF 3-DIBUTYNYL AND 4-DIPENTYNYL PYRIDINE-2,6-DICARBOXYLATE
}

\author{
(Sintesis dan Kajian Sinar-X Hablur Tunggal 3-dibutinil dan 4-dipentinil piridina-2,6- \\ dikarboksilat) \\ Nawwar Hanun Abdul Malek ${ }^{1}$, Mohammad Fadzlee Ngatiman ${ }^{2}$, Bohari M. Yamin ${ }^{1}$, Nurul Izzaty Hassan ${ }^{1}$ * \\ ${ }^{I}$ School of Chemical Sciences and Food Technology, Faculty of Science and Technology \\ ${ }^{2}$ Centre for Research and Instrumentation Management, \\ Universiti Kebangsaan Malaysia, 43600 UKM Bangi, Selangor, Malaysia \\ *Corresponding author: drizz@ukm.edu.my
}

Received: 7 March 2017; Accepted: 19 July 2017

\begin{abstract}
Two pyridine-2,6-dicarboxylates each containing butynyl and pentynyl at position 2 and 6 were synthesized by esterification of 2,6-pyridinedicarbonyl dichloride with $N$-alkyne alcohol. All compounds were characterized by using nuclear magnetic resonance spectroscopy (NMR), infrared spectroscopy (IR) and mass spectrometry (MS) techniques. Crystallographic studies showed that both compounds, 3-dibutynyl pyridine-2,6-dicarboxylate (3a) and 4-dipentynyl pyridine-2,6-dicarboxylate (3b) crystallized in monoclinic system with same space group of $\mathrm{C} 2 / \mathrm{c}$.
\end{abstract}

Keywords: diester macrocyclic, esterification, X-Ray structural study

\begin{abstract}
Abstrak
Dua sebatian piridina dikarboksilat, 3-dibutinil dan 4-dipentinil pada kedudukan 2 dan 6 telah berjaya disintesiskan dengan tindak balas pengesteran di antara 2,6-piridinadikarbonil diklorida dengan $N$-alkuna alkohol. Setiap sebatian berjaya dicirikan dengan teknik spektroskopi resonans magnetik nuklear (RMN), infra merah (IR) dan spektrometri jisim (MS). Kajian kristalografi menunjukkan sebatian 3-dibutinil piridina-2,6-dikarboksilat (3a) dan 4-dipentinil piridina-2,6-dikarboksilat (3b) terhablur dalam sistem monoklinik dengan kumpulan ruang $\mathrm{C} 2 / \mathrm{c}$.
\end{abstract}

Kata kunci: makrosiklik diester, tindak balas pengesteran, kajian struktur sinar-X

\section{Introduction}

The synthesis study of macrocyclic has been rapidly developed for almost 40 years [1]. The design of this compound can be varies depending on the linker being used such as pyridine, benzene or aliphatic chain. The side chain can be functional group of ester, ether, thiourea, alkyne and alkene [2-7]. Various derivatives have been reported due to straightforward preparation and potential in biological activities and medicine.

Macrocyclic compound is an important reference compound in chemistry studies such as complexation to metal due to existence electron donating atom in the ligand [8-9]. Some of macrocyclic derivatives have been reported showing great capability in antibacterial, anticancer and HIV treatment [10-14]. Besides that, macrocyclic compounds contained alkene or alkyne ligands have been studied in recent trend of metathesis reaction. This 
reaction has been shown to facilitate several complicated reaction steps especially in natural product synthesis such as lactones and marine alkaloid nakadomarin A [15].

Esters are commonly synthesized from the condensation reaction between carboxylic acid and alcohol with the loss of water. The esters can also be prepared by other reactions using acid anhydrides, acid chloride, unsaturated hydrocarbon, amides, nitriles, ethers, aldehydes, ketones, alcohols, and ester itself. The synthesis of these macrocyclic were carried out by esterification reaction with acyl chloride and alkyne alcohol in the presence of triethylamine as a base. The nitrogen's lone pair of triethylamine assisted the deprotonation of hydrogen at hydroxyl to initiate the esterification reaction.

This is demonstrated in the present work where pyridine acyl chloride was reacted with alkyne alcohol to form pyridine bridged diester macrocyclic followed by 3-and 4-dialkyne to form 3-dibutynyl pyridine-2,6-dicarboxylate 3a and 4-dipentynyl pyridine-2,6-dicarboxylate 3b, respectively (Scheme 1). With the help of X-ray structure, we could see either the presence of lone pair of nitrogen pyridine, position of the ester on ring or the $s p$ hybridization of alkyne would give effect on geometry of the isomers. Following this, the designing of next product for future study, especially in complexation or metathesis reaction become facile. Thus, the synthesis, characterization and X-ray structures of the isomers are presented.

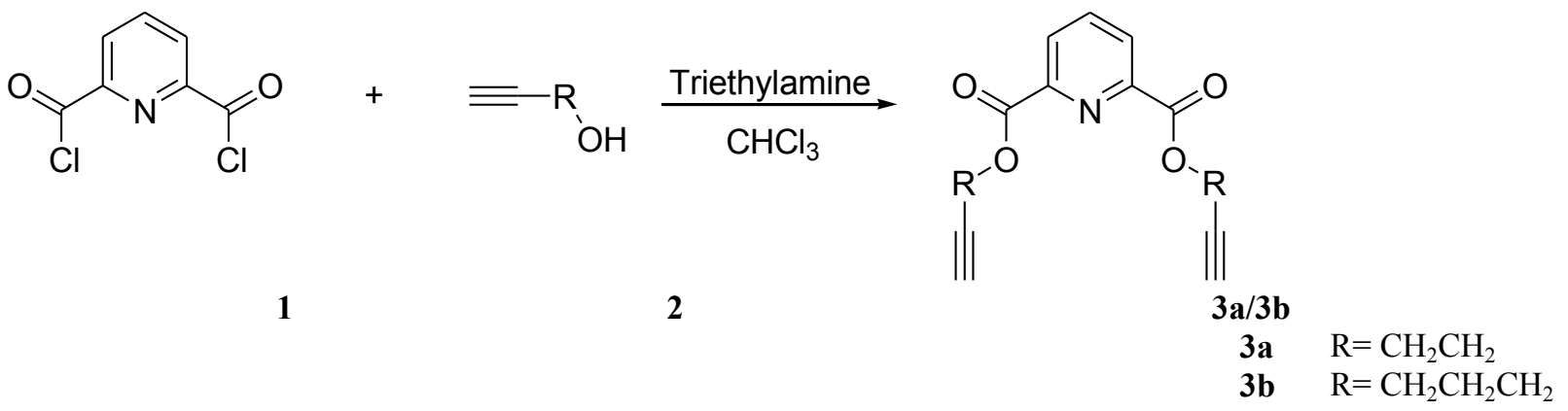

Scheme 1. Synthesis of N-dialkyne pyridine-2,6-dicarboxylate, 3a and $3 b$ at ambient temperature with percentage yield of $76 \%$ and $63 \%$

\section{Materials}

Materials and Methods

2,6-pyridinedicarbonyl dichloride, 3-butyn-1-ol, 4-pentyn-1-ol, triethylamine, chloroform, cyclohexane and ethyl acetate were purchased from Sigma Aldrich. Other chemicals were analytical grades and used as received.

\section{Instruments}

The reactions were monitored by thin-layer chromatography (TLC) using $0.25 \mathrm{~mm}$ silica gel plates (Merck Kieselgel $60 \mathrm{~F}_{254} \mathrm{UV}$ indicator). Column chromatography was performed using silica gel Merck Kieselgel (230-400 mesh). The NMR spectra were recorded by Bruker spectrometer at $400 \mathrm{MHz}$ for ${ }^{1} \mathrm{H}$ NMR using tetramethylsilane (TMS) as internal standard and $100 \mathrm{MHz}$ for ${ }^{13} \mathrm{C}$ NMR. The coupling constant $(J)$ are given in $\mathrm{Hz}$. IR spectra were recorded in the range of 4000-370 $\mathrm{cm}^{-1}$ using a Perkin Elmer Spectrum GX with samples prepared as $\mathrm{KBr}$ pellets. The melting point was determined by using Barnstead Electrothermal IA9000 Series Melting Point Apparatus with oven temperature range ambient to $400{ }^{\circ} \mathrm{C}$. The Mass spectrometry was recorded by Bruker MicroToF Q with method of direct infuse and source type electro-spray ionization (ESI).

\section{Synthesis of $\boldsymbol{N}$-dialkyne pyridine-2,6-dicarboxylate}

2,6-pyridinedicarbonyl dichloride $(4.9 \mathrm{mmol}, 1 \mathrm{~g})$ was dissolved in $25 \mathrm{~mL}$ chloroform inside the one-neck round bottom flask. Alkyne alcohol solution $(9.8 \mathrm{mmol})$ is added into the mixture followed with $2.1 \mathrm{~mL}$ of triethylamine. The mixture was stirred at $0{ }^{\circ} \mathrm{C}$ for 10 minutes and continued stir at room temperature for 18 hours. The mixture 
then dried under vacuum and the residue purified by flash chromatography (cyclohexane/ethyl acetate) to give colorless crystal upon evaporation. The crystals are suitable for X-ray study.

\section{Results and Discussion}

Representative data for synthesis 3-dibutynyl pyridine-2,6-dicarboxylate, 3a

The compound was obtained as colorless crystal in $76 \%$ yield after recrystallization. Mp $86-87{ }^{\circ} \mathrm{C}$. IR $(\mathrm{KBr}$ pellets) $\mathrm{v} / \mathrm{cm}^{-1}$ : 3264 (stretching $\left.\mathrm{C} \equiv \mathrm{C}\right), 1716(\mathrm{C}=\mathrm{O}), 1327($ Ar-N), $1244(\mathrm{C}-\mathrm{O}), 693$ (bending $\mathrm{C} \equiv \mathrm{C}) . ;{ }^{1} \mathrm{H}$ NMR $(400$ $\left.\mathrm{MHz} ; \mathrm{CDCl}_{3}\right) \delta_{\mathrm{H} 2.06}(2 \mathrm{H}, \mathrm{s}, \mathrm{C} \equiv \mathrm{CH}), 2.73\left(4 \mathrm{H}, \mathrm{t}, \mathrm{J}=6.8,2 \mathrm{xCH}_{2} \mathrm{C} \equiv \mathrm{CH}\right), 4.52\left(4 \mathrm{H}, \mathrm{t}, \mathrm{J}=7.2,2 \mathrm{xOCH}_{2} \mathrm{CH}_{2} \mathrm{C} \equiv \mathrm{CH}\right)$, $8.02(1 \mathrm{H}, \mathrm{t}, \mathrm{J}=7.6, \mathrm{ArH}), 8.30(2 \mathrm{H}, \mathrm{d}, \mathrm{J}=7.6,2 \mathrm{xArH}) .{ }^{13} \mathrm{C} \mathrm{NMR}\left(100 \mathrm{MHz} ; \mathrm{CDCl}_{3}\right) \delta_{\mathrm{C}} 18.9\left(\mathrm{CH}_{2} \mathrm{C} \equiv \mathrm{CH}\right), 63.6(\mathrm{O}-$ $\left.\mathrm{CH}_{2}\right), 70.3(\mathrm{C} \equiv \mathrm{CH}), 79.5(\mathrm{C} \equiv \mathrm{CH}), 128.2(\mathrm{ArCH}), 138.4(\mathrm{ArCH}), 148.1(\mathrm{ArC}), 164.1(C=\mathrm{O}) . \mathrm{HRMS}\left(\mathrm{ES}^{+}\right) \mathrm{m} / \mathrm{z}$ calculated for $\mathrm{C}_{15} \mathrm{H}_{13} \mathrm{NO}_{4} \mathrm{Na}[\mathrm{M}+\mathrm{Na}]^{+}$294.2578, found 294.0740.

\section{Representative data for synthesis 4-dipentynyl pyridine-2,6-dicarboxylate, $3 \mathrm{~b}$}

The compound was obtained as colorless crystalline in $63 \%$ yield after recrystallization. Mp $80-82{ }^{\circ} \mathrm{C}$. IR $(\mathrm{KBr}$ pellets) $\mathrm{v} / \mathrm{cm}^{-1}: 3278$ (stretching $\left.\mathrm{C} \equiv \mathrm{C}\right), 1736(\mathrm{C}=\mathrm{O}), 1288(\mathrm{Ar}-\mathrm{N}), 1237(\mathrm{C}-\mathrm{O}), 693$ (bending $\left.\mathrm{C} \equiv \mathrm{C}\right) .{ }^{1} \mathrm{H}$ NMR $(400$ $\left.\mathrm{MHz} ; \mathrm{CDCl}_{3}\right) \delta_{\mathrm{H} 2.01}(2 \mathrm{H}, \mathrm{s}, \mathrm{C} \equiv \mathrm{CH}), 2.09\left(4 \mathrm{H}, \mathrm{t}, \mathrm{J}=8,2 \mathrm{xCH}_{2} \mathrm{C} \equiv \mathrm{CH}\right), 2.41\left(4 \mathrm{H}, \mathrm{q}, \mathrm{J}=4,2 \mathrm{xCH}_{2} \mathrm{CH}_{2} \mathrm{C} \equiv \mathrm{CH}\right), 4.54$ $\left(4 \mathrm{H}, \mathrm{t}, \mathrm{J}=8,2 \mathrm{xO}-\mathrm{CH}_{2} \mathrm{CH}_{2} \mathrm{CH}_{2} \mathrm{C} \equiv \mathrm{CH}\right), 8.02(1 \mathrm{H}, \mathrm{t}, \mathrm{J}=8, \mathrm{ArH}), 8.27(2 \mathrm{H}, \mathrm{d}, \mathrm{J}=8,2 \mathrm{xArH}) .{ }^{13} \mathrm{C}$ NMR $(100 \mathrm{MHz}$; $\left.\mathrm{CDCl}_{3}\right) \delta_{\mathrm{C}} 15.27\left(\mathrm{CH}_{2} \mathrm{C} \equiv \mathrm{CH}\right), 27.45\left(\mathrm{O}-\mathrm{CH}_{2}-\mathrm{CH}_{2}\right) 64.70\left(\mathrm{O}-\mathrm{CH}_{2}\right), 69.26(\mathrm{C} \equiv \mathrm{CH}), 82.87(\mathrm{C} \equiv \mathrm{CH}), 127.90(\mathrm{ArCH})$, 138.25 (ArCH), $148.44(\mathrm{ArC}), 164.51(\mathrm{C}=\mathrm{O})$. HRMS $(\mathrm{ES}+) \mathrm{m} / \mathrm{z}$ calculated for $\mathrm{C}_{17} \mathrm{H}_{17} \mathrm{NO}_{4} \mathrm{Na}[\mathrm{M}+\mathrm{Na}]^{+} 322.3109$, found 322.1158 .

\section{Characterization}

The infrared spectra for both ester macrocyclic isomers, 3a and $\mathbf{3 b}$ showed the presence of the stretching frequency at 3264 and $3278 \mathrm{~cm}^{-1}$ due to the existence of terminal alkyne. The peak at 1716 and $1740 \mathrm{~cm}^{-1}$ are the stretching frequencies for the $v(\mathrm{C}=\mathrm{O})$. For the peak at 1327 and $1288 \mathrm{~cm}^{-1}$ are referred to aromatic amine of the pyridine and peak at 1244 and $1237 \mathrm{~cm}^{-1}$ are for the ether group. Sharp peak at 693 and $654 \mathrm{~cm}^{-1}$ are referring to bending mode of the terminal alkyne. Figure 1(a) display the IR spectrum of $\mathbf{3 a}$ and (b) for compound $\mathbf{3 b}$.

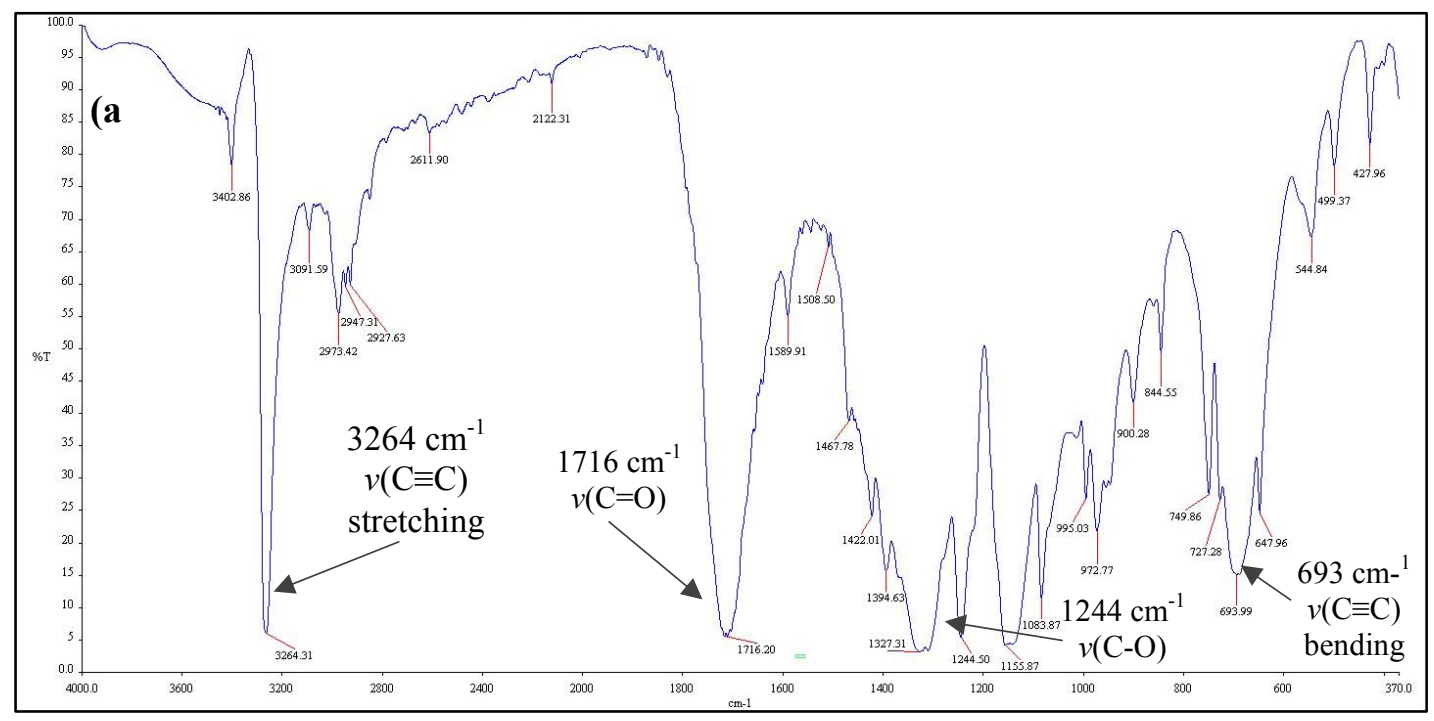




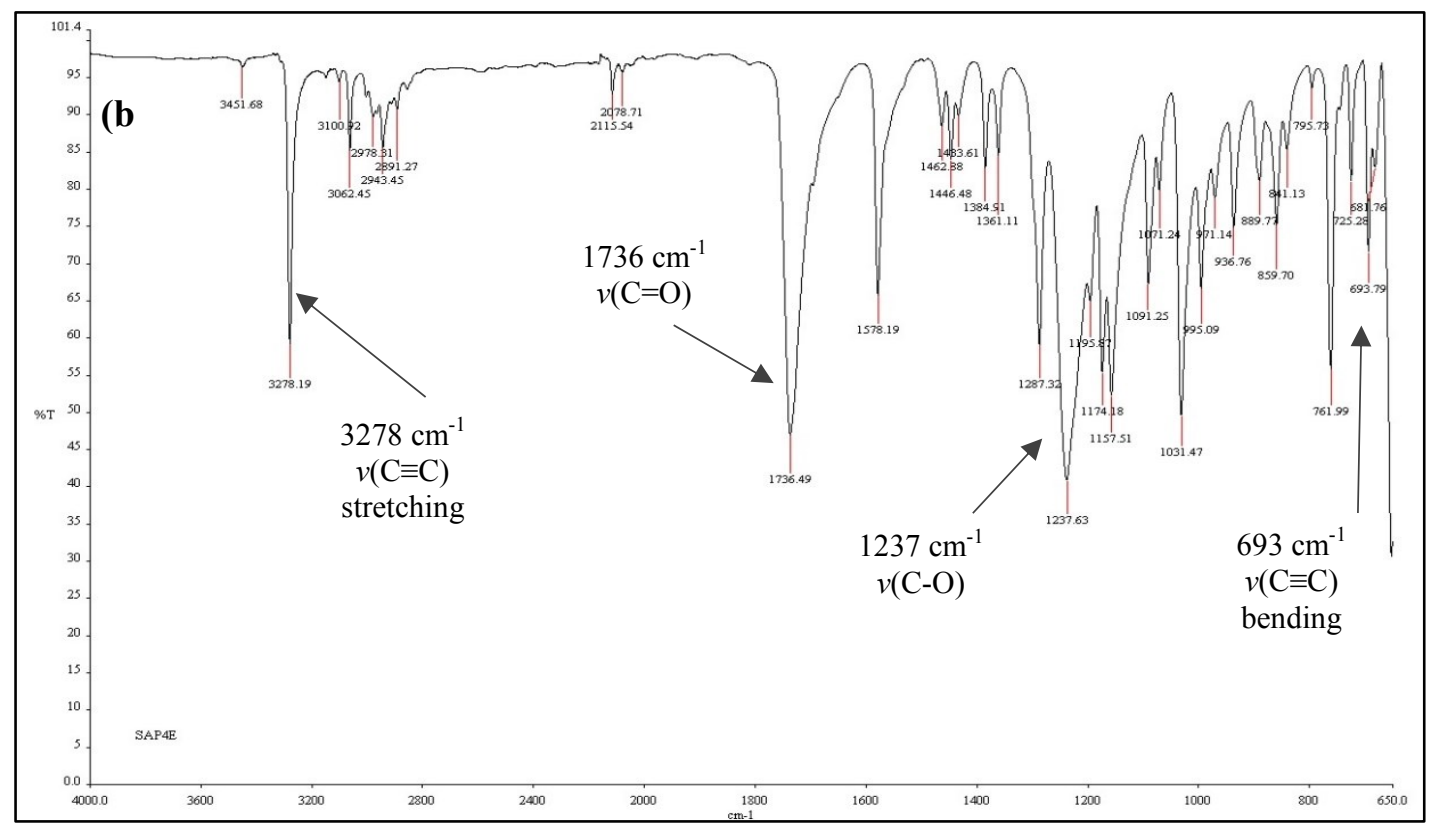

Figure 1. The IR spectrum of (a) $\mathbf{3 a}$ and (b) $\mathbf{3 b}$

The chemical shifts of the pyridine rings protons for the both isomers are similar and appeared as a dublet at 12.0 and a triplet at $11.0 \mathrm{ppm}$, respectively. The terminal alkynes protons for the compounds $\mathbf{3 a}$ and $\mathbf{3 b}$ were found in the range of 1.0-2.0 ppm. The chemical shifts of the methylene protons near the alkyne $\left(-\mathrm{CH}_{2} \mathrm{C} \equiv \mathrm{CH}\right)$ appeared at the range of 2.07-5.02 ppm while the methylene protons's chemical shifts are found at $4.50 \mathrm{ppm}$. In the ${ }^{13} \mathrm{C} \mathrm{NMR}$ spectra, the carbon chemical shifts of $\mathrm{C}=\mathrm{O}$ is found at $174.0 \mathrm{ppm}$, respectively for the both isomers. The aromatic pyridine carbon chemical shifts of the isomers appeared in the range of 124.5-136.0 ppm. The chemical shift for the terminal alkyne observed at the range of 21.1-43.8 ppm. The value of molecular ion peak found in mass spectrometry for $\mathbf{3 a}$ and $\mathbf{3 b}$ are agreed with the expected molecular weight, respectively.

\section{X-ray crystallographic study}

The colorless crystals of $\mathbf{3 a}$ and $\mathbf{3 b}$ are crystallized in monoclinic system with same space group of $\mathrm{C} 2 / \mathrm{c}$. The crystallographic data are summarized in Table 1.

Table 1. Crystal data and structure refinement for the compounds $\mathbf{3 a}$ and $\mathbf{3 b}$.

\begin{tabular}{lll}
\hline Crystal Parameters & $\mathbf{3 a}$ & $\mathbf{3 b}$ \\
\hline CCDC deposition number & 1535752 & 1536022 \\
Empirical formula & $\mathrm{C}_{15} \mathrm{H}_{11} \mathrm{~N} \mathrm{O}_{4}$ & $\mathrm{C}_{17} \mathrm{H}_{17} \mathrm{~N} \mathrm{O}_{4}$ \\
Formula weight & 269.25 & 299.31 \\
Temperature & $303(2) \mathrm{K}$ & $303(2) \mathrm{K}$ \\
Wavelength & $0.71073 \AA$ & $0.71073 \AA$ \\
Crystal system & Monoclinic & Monoclinic \\
Space group & $\mathrm{C} 2 / \mathrm{c}$ & $\mathrm{C} 2 / \mathrm{c}$ \\
Unit cell dimensions & $\mathrm{a}=13.2710(16) \AA$ & $\mathrm{a}=24.577(4) \AA$ \\
& $\mathrm{b}=11.7023(14) \AA$ & $\mathrm{b}=6.3136(9) \AA$ \\
& $\mathrm{c}=8.9657(10) \AA$ & $\mathrm{c}=10.5608(14) \AA$ \\
& $\alpha=90^{\circ}$ & $\alpha=90^{\circ}$ \\
& $\beta=102.672(4)^{\circ}$ & $\beta=99.562(5)^{\circ}$ \\
& $\gamma=90^{\circ}$ & $\gamma=90^{\circ}$ \\
\hline
\end{tabular}


Table 1 (cont'd). Crystal data and structure refinement for the compounds $\mathbf{3 a}$ and $\mathbf{3 b}$.

\begin{tabular}{lll}
\hline Crystal Parameters & $\mathbf{3 a}$ & $\mathbf{3 b}$ \\
\hline Volume & $1358.5(3) \AA^{3}$ & $1616.0(4) \AA^{3}$ \\
Z & 4 & 4 \\
Density (calculated) & $1.316 \mathrm{Mg} / \mathrm{m}^{3}$ & $1.230 \mathrm{Mg} / \mathrm{m}^{3}$ \\
Absorption coefficient & $0.097 \mathrm{~mm}^{-1}$ & $0.088 \mathrm{~mm}^{-1}$ \\
$\mathrm{~F}(000)$ & 560 & 632 \\
Crystal size & $0.480 \times 0.300 \times 0.130 \mathrm{~mm}^{3}$ & $0.480 \times 0.160 \times 0.080 \mathrm{~mm}^{3}$ \\
Theta range for data collection & 3.053 to $24.972^{\circ}$ & 3.334 to $24.966^{\circ}$ \\
Index ranges & $-15<=\mathrm{h}<=15$, & $-28<=\mathrm{h}<=28$, \\
& $-13<=\mathrm{k}<=13$, & $-7<=\mathrm{k}<=7$, \\
& $-9<=1<=10$ & $-12<=1<=12$ \\
Reflections collected & 18132 & 16291 \\
Independent reflections & $1197[\mathrm{R}($ int $)=0.0714]$ & $1420[\mathrm{R}($ int $)=0.0988]$ \\
Completeness to theta & $99.9 \%$ & $99.9 \%$ \\
Max. and min. transmission & 0.988 and 0.955 & 0.993 and 0.959 \\
Refinement method & Full-matrix least-squares on $\mathrm{F}^{2}$ & $\mathrm{Full}-\mathrm{matrix}$ least squares on $\mathrm{F}^{2}$ \\
Data / restraints / parameters & $1197 / 0 / 92$ & $1420 / 1 / 101$ \\
Goodness-of-fit on $\mathrm{F}^{2}$ & 1.071 & 1.372 \\
Final R indices [I $>2$ sigma(I)] & $\mathrm{R} 1=0.0734$, & $\mathrm{R} 1=0.1094$, \\
& $\mathrm{wR} 2=0.1969$ & $\mathrm{wR} 2=0.2461$ \\
R indices (all data) & $\mathrm{R} 1=0.1031$, & $\mathrm{R} 1=0.1695$, \\
& $\mathrm{wR} 2=0.2305$ & wR2 $=0.2763$ \\
Largest diff. peak and hole & 0.391 and -0.322 e. $\AA^{-3}$ & 0.735 and -0.587 e. $\AA^{3}$ \\
\hline
\end{tabular}

Figure 2 shows the structure molecular with labels of the molecules $\mathbf{3 a}$ and $\mathbf{3 b}$. Both molecules with the pyridine linker and both side chains groups, respectively adopt a cis-cis against the $\mathrm{C}=\mathrm{O}$ bond. The two molecules have asymmetric unit of $1 / 2$ independence molecule generated since they are centrosymmetric across the N1/C 8 and N1/C9 atoms.

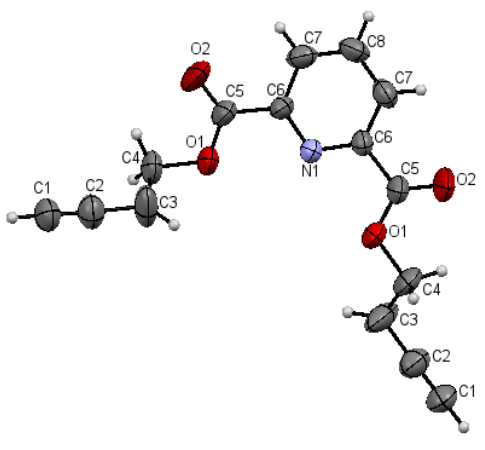

3a

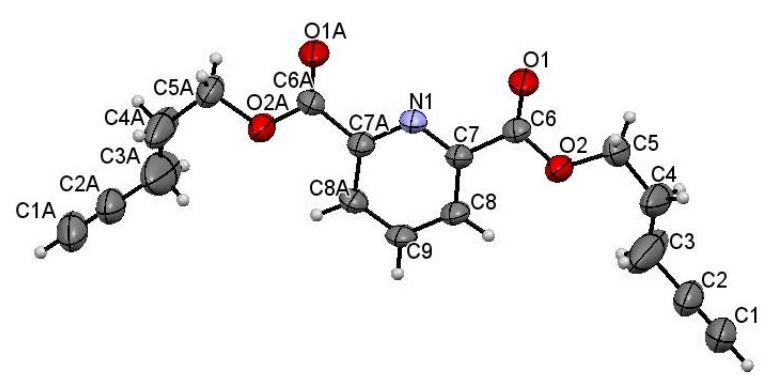

3b

Figure 2. ORTEP diagrams of compund $3 \mathrm{a}$ and $3 \mathrm{~b}$ drawn at $50 \%$ probability displacement ellipsoids

Compound 3a possess a planar geometry by its pyridine ring N1/(C6-C8)/C6a-C7a) with the ester C4-C5/O1-O2 and $\mathrm{C} 4 \mathrm{a}-\mathrm{C} 5 \mathrm{a} / \mathrm{O} 1 \mathrm{a}-\mathrm{O} 2 \mathrm{a}$ with maximum deviation of $0.016 \AA$ for atom $\mathrm{C} 4$. The pyridine and ester groups are 
Nawwar Hanun et al: SYNTHESIS AND X-RAY SINGLE CRYSTAL STUDY OF 3-DIBUTYNYL AND 4-DIPENTYNYL PYRIDINE-2,6-DICARBOXYLATE

perpendicular with the alkyne side chain with dihedral angle to the ester at $\mathrm{C} 5 / \mathrm{O} 1 / \mathrm{C} 4 / \mathrm{C} 3$ with $-139.8(4)^{\circ}$. As for compound $\mathbf{3 b}$, all atoms are in planar with maximum deviation at $\mathrm{C} 8$ with $0.052(4) \AA$. The bond lengths and angles are in normal ranges for both compounds (Table 2).

Table 2. Selected Bond Lengths $(\AA)$ and Bond Angles $\left(^{\circ}\right)$ for Compounds 3a and $\mathbf{3 b}$

\begin{tabular}{lclc}
\hline & Compound 3a & \multicolumn{2}{c}{ Compound 3b } \\
\hline Bond & Dist. & Bond & Dist. \\
\hline O1-C5 & $1.300(4)$ & O1-C6 & $1.193(5)$ \\
O1-C4 & $1.456(4)$ & O2-C6 & $1.327(5)$ \\
O2-C5 & $1.177(4)$ & O2-C5 & $1.458(6)$ \\
N1-C6\#1 & $1.332(3)$ & N1-C7 & $1.337(5)$ \\
N1-C6 & $1.333(3)$ & N1-C7\#1 & $1.337(5)$ \\
C1-C2 & $1.166(5)$ & C1-C2 & $1.127(8)$ \\
C2-C3 & $1.463(5)$ & C2-C3 & $1.405(10)$ \\
C3-C4 & $1.455(6)$ & C3-C4 & $1.504(8)$ \\
C5-C6 & $1.492(4)$ & C4-C5 & $1.449(9)$ \\
C6-C7 & $1.386(5)$ & C6-C7 & $1.493(6)$ \\
C7-C8 & $1.360(4)$ & C7-C8 & $1.391(6)$ \\
C8-C7\#1 & $1.360(4)$ & C8-C9 & $1.369(6)$ \\
& & C9-C8\#1 & $1.369(6)$ \\
\hline Angle & $\left({ }^{\circ}\right)$ & Angle & $\left({ }^{\circ}\right)$ \\
\hline C5-O1-C4 & $116.5(3)$ & C6-O2-C5 & $117.1(4)$ \\
C6\#1-N1-C6 & $115.8(4)$ & C7- $1-C 7 \# 1$ & $117.1(5)$ \\
C1-C2-C3 & $178.1(4)$ & C1-C2-C3 & $169.7(10)$ \\
C4-C3-C2 & $112.2(3)$ & C2-C3-C4 & $115.9(8)$ \\
C3-C4-O1 & $108.2(3)$ & C5-C4-C3 & $123.2(7)$ \\
O2-C5-O1 & $123.4(3)$ & C4-C5-O2 & $109.7(5)$ \\
O2-C5-C6 & $121.5(3)$ & O1-C6-O2 & $122.6(5)$ \\
O1-C5-C6 & $115.2(3)$ & O1-C6-C7 & $126.1(4)$ \\
N1-C6-C7 & $123.8(3)$ & O2-C6-C7 & $111.3(4)$ \\
N1-C6-C5 & $119.0(3)$ & N1-C7-C8 & $123.0(5)$ \\
C7-C6-C5 & $117.2(3)$ & N1-C7-C6 & $115.3(4)$ \\
C8-C7-C6 & $118.9(3)$ & C8-C7-C6 & $121.6(4)$ \\
C7\#1-C8-C7 & $118.7(4)$ & C9-C8-C7 & $119.0(5)$ \\
& & C8\#1-C9-C8 & $118.9(6)$ \\
\hline
\end{tabular}

In the crystal structure, the $\mathbf{3 a}$ molecule is linked by $\mathrm{C} 1-\mathrm{H} 1 \cdots \mathrm{O} 2$ intermolecular hydrogen bond. In contrast with molecule 3b, linked by nitrogen of pyridine with the hydrogen methine of $\mathrm{C} 9$ pyridine, $\mathrm{N} 1 \cdots \mathrm{H} 9-\mathrm{C} 9$ and oxygen carbonyl and hydrogen methine of $\mathrm{C} 8$ pyridine, $\mathrm{C} 8-\mathrm{H} 8 \cdots \mathrm{O} 1$ (Table 3). The intermolecular hydrogen bond for molecule 3a and $\mathbf{3 b}$ formed a network of polymorph at b-axis and c-axis (Figure 3 ).

Table 3. Hydrogen Bond Lengths ( $\AA$ ) and Bond Angles for Compounds 3a and 3b

\begin{tabular}{llccccl}
\hline Compound & D- $\mathbf{H}^{\cdots \cdots} \cdot \mathbf{A}$ & $\mathbf{D}-\mathbf{H}$ & $\mathbf{H}^{\cdots \cdots} \cdot \mathbf{A}$ & $\mathbf{D}^{\cdots \cdots} \cdot \mathbf{A}$ & $\mathbf{D}-\mathbf{H}^{\cdots \cdots} \cdot \mathbf{A}$ & Symmetry code \\
\hline 3a & $\mathrm{C} 1-\mathrm{H} 1 \cdots \cdots \cdot \mathrm{O} 2 \# 2$ & 0.93 & 2.25 & $3.131(6)$ & 159 & $1 / 2-\mathrm{x}, 1 / 2+\mathrm{y},-1 / 2-\mathrm{z}$ \\
$\mathbf{3 b}$ & $\mathrm{C} 8-\mathrm{H} 8 \cdots \cdots \cdot \mathrm{O} 1 \$ 1 \# 2$ & 0.93 & 2.51 & $3.182(6)$ & 129.3 & $-\mathrm{x}+2, \mathrm{y},-\mathrm{z}+1 / 2$ \\
& $\mathrm{C} 9-\mathrm{H} 9 \cdots \cdots \cdot \mathrm{N} 1 \# 2$ & 0.93 & 2.60 & $3.531(8)$ & 180 & $2 \mathrm{x}, \mathrm{y}-1, \mathrm{z}$ \\
\hline
\end{tabular}




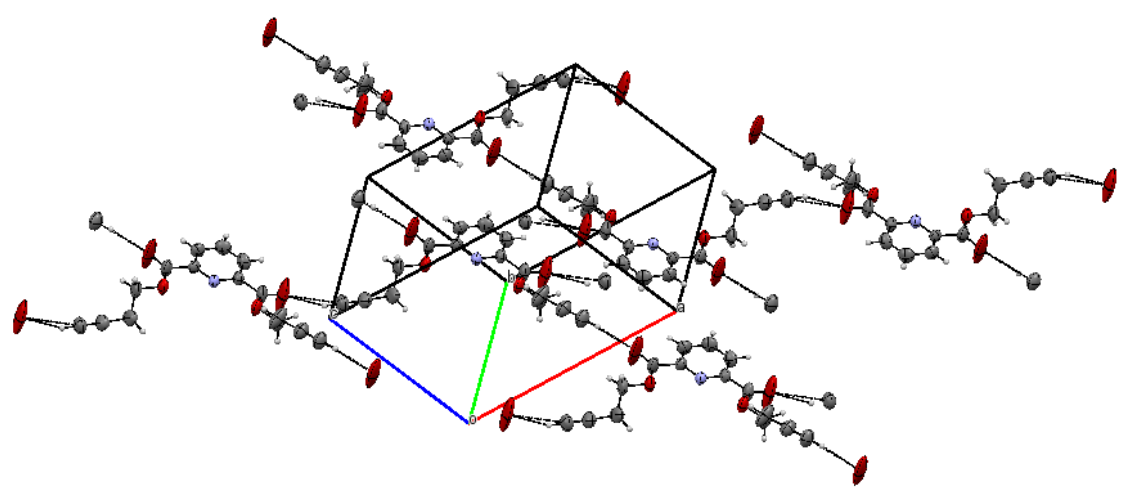

3a

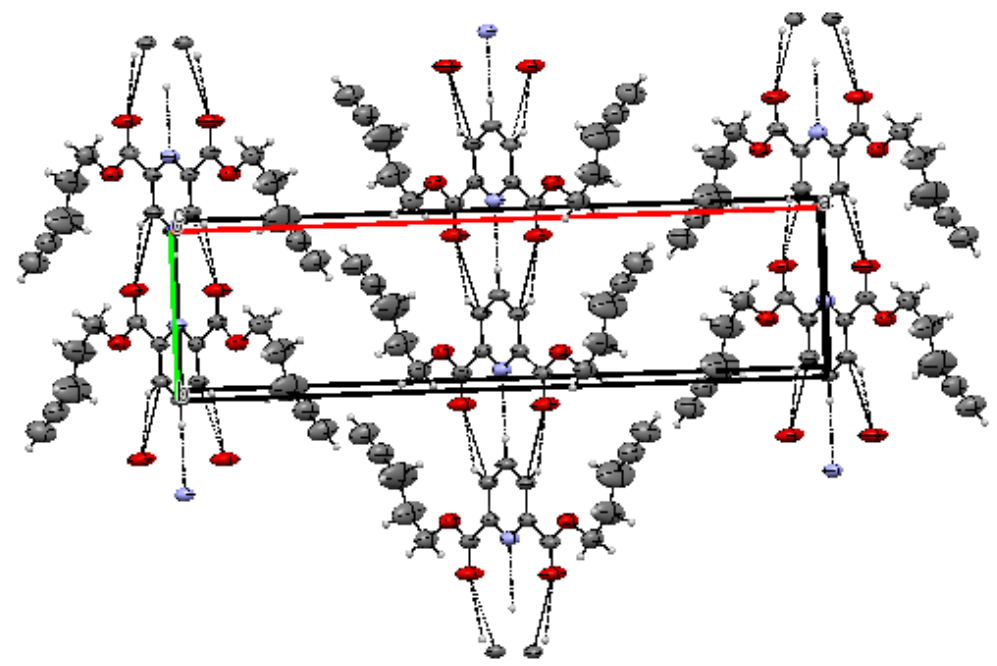

$3 \mathbf{b}$

Figure 3. Polymorph network of molecule at b-axis (3a) and c-axis (3b). The dash line indicates the intermolecular hydrogen bond

\section{Conclusion}

The ester macrocyclic 3-dibutynyl-2,6-pyridine dicarboxylate and 4-dipentynyl-2,6-dicarboxylate were successfully synthesized by condensation reaction and fully characterized using spectroscopic techniques. Both compounds were crystallized in the solvent system of cyclohexane and ethyl acetate for purification and afforded colorless and needle-liked crystals. The observation on CCDC data has no record on these compounds. Both compounds have monoclinic system with space group of $\mathrm{C} 2 / \mathrm{c}$ but different geometry as $\mathbf{3 b}$ showed fully geometry planar. The intermolecular hydrogen bond gave the compounds a polymorph network in the crystal structure. The terminal alkynes on both compounds are suitable metathesis reaction. Thus, further study on the metathesis reaction and optimization to obtain cyclic compounds are in progress.

\section{Acknowledgement}

The authors thank the Ministry of Higher Education of Malaysia and Universiti Kebangsaan Malaysia for the research grant GUP-2016-059. The assistance of Mr Mohammad Fadzlee bin Ngatiman at Centre of Research and 
Instrumentation Management. One of the authors, Nawwar Hanun would like to thank the Ministry of Higher Education of Malaysia for the Mybrain15 scholarship.

\section{References}

1. Newkome, G. R., Sauer, J. S., Roper, J. M. and Hager, D. C. (1976). Construction of synthetic macrocyclic compounds possesing subheterocyclic rings, specifically pyridine, furan and thiophene. Chemical Review, 77: $513-597$.

2. Garren E. Maas, G. E., Bradshaw, J. S., Izatt, R. M. and Christensen, J. J. (1977). Synthesis of a new series of macrocyclic polyether-diester ligands. Journal of Organic Chemistry, 42: 3937 - 3941.

3. Bradshaw, J. S. and Thompson, M. D. (1978). Synthesis of macrocyclic polyether-diester compounds with an aromatic subcyclic unit. Journal of Organic Chemistry, 43: $2456-2460$.

4. Potts, K. T., Cipullo, M. J., Ralli, P. and Theodoridis, G. (1982). Synthesis of 2,6-disubstituted pyridines, polypyridinyls and annulated pyridines. Journal of Organic Chemistry, 47: 3027 - 3038.

5. Zhao, H. and Hua, W. (2000). Synthesis and characterization of pyridine-based polyamido-polyester optically active macrocycles and enantiomeric recognition for d- and 1- amico acid methyl ester hydrochloride. Journal of Organic Chemistry, 65: 2933 - 2938.

6. Vedernikov, A. N., Pink, M. and Caulton, K. G. (2003). Design and synthesis of tridentate facially chelating ligands of the [2.n.1]-(2,6)-pyridinophane family. Journal of Organic Chemistry, 68: $4806-4814$.

7. Newkome, G. R., Patri, A. K., Holder, E. and Schubert, U. S. (2004). Synthesis of 2,2'-bipyridines: versatile building blocks for sexy architectures and functional nanomaterials. European Journal of Organic Chemistry, 2004(2): $235-254$.

8. Kolthoff, I. M. (1979). Application of macrocyclic compounds in chemical analysis. Analytical Chemistry, 51: $1-22$.

9. Bradshaw, J. S., Maas, G. E., Lamb, J. D., Izatt, R. M. and Christensen, J. J. (1980). Cation complexing properties of synthetic macrocyclic polyether-diester ligands containing the pyrdine subcyclic unit. Journal of the American Chemical Society, 2: $467-474$.

10. Al-Salahi, R. A., Al-Omar, M. A. and Amr, A. E. E. (2010). Synthesis of new macrocyclic polyamides as antimicrobial agent candidates. Molecules, 15: $6588-6597$.

11. El-Salam, O. I. A., Al-Omar, M. A., Fayed, A. A., Flefel, E. M. and Amr, A. E. E. (2012). Synthesis of new macrocyclic polyamides as antimicrobial agent candidates. Molecules, 17: 14510-14521.

12. Kuz’min, V. E., Lozitsky, V. P., Kamalov, G. L., Lozitskaya, R. N., Zheltvay, A. I., Fedtchouk, A. S. and Kryzhanovsky, D. N. (2000). Analysis of the structure - anticancer activity relationship in a set of Schiff bases of macrocyclic 2,6-bis(2- and 4-formylaryloxymethyl)pyridines. Acta Biochimica Polonica, 47: 867 - 875.

13. Santini, C., Pellei, M., Gandin, V., Porchia, M., Tisato, F. and Marzano, C. (2003). Advances in copper complexes as anticancer agents. Chemical Review, 114(1): 815 - 862.

14. Rusconi, S., Cicero, M. L., Viganò, O., Sirianni, F., Bulgheroni, El., Ferramosca, S., Bencini, A., Bianchi, A., Ruiz, L., Cabrera, C., Martinez-Picado, J., Supuran, C. T. and Galli, M. (2009). New macrocyclic amines showing activity as HIV entry inhibitors against wild type and multi-drug resistant viruses. Molecules, 14: 1927 -1937 .

15. Fürstner,A., Guth, O., Rumbo, A. and Seidel, G. (1999). Ring closing alkyne metathesis. Comparative investigation of two different catalyst systems and application to the stereoselective synthesis of olfactory lactones, azamacrolides, and the macrocyclic perimeter of the marine alkaloid nakadomarin A. Journal of American Chemical Society, 121: 11108 - 11113. 